\title{
Letter: Genetic databases and donor anonymity
}

Sir,

We read with interest the opinion piece from Guido Pennings on "Genetic databases and the future of donor anonymity" (Pennings 2019). He raises a number of points which merit a response.

Pennings suggests that "good matches guaranteeing a close genetic relationship are at the moment relatively rare" in direct-to-consumer (DTC) DNA databases but "that might change in the future". However, the future is already here. When we first warned about the end of donor anonymity in 2016 (Harper, Kennett, and Reisel 2016) around three million people had taken a DTC DNA test. The market has grown exponentially in the last three years, and the four largest companies have now tested nearly 30 million people. AncestryDNA reported in May 2019 that they had a database of over 15 million completed samples (Ancestry Corporate 2019). 23andMe has tested over 10 million people (23andMe 2019). MyHeritage has a database of 2.5 million people, while FamilyTreeDNA has over two million users (Regalado 2019). The number of people who have taken a DNA test is expected to grow to 100 million by 2021 (Khan and Mittelman 2018). Although the initial growth of the market took place in the US, DNA testing is becoming increasingly popular throughout the Englishspeaking world. MyHeritage DNA has a website in many different European languages and is penetrating the market in non-English-speaking countries. MyHeritage's role as a presenting partner of the 2019 Eurovision Song Contest is likely to lead to a further expansion in Europe (MyHeritage 2018).

Pennings suggests that the evidence for the harm of late or inadvertent disclosure is "weak or non-existent". It is true that very few studies have been able to address this complex issue in a satisfactory way. The only longitudinal study, conducted by Susan Golombok's team at Cambridge, found that families who had disclosed donor conception to their children in the preschool years generally showed more positive outcomes (Ilioi et al. 2017). However, it is also well-known that there is a significant gap between disclosure intention and actual disclosure (Readings et al. 2011). This suggests that the longer parents wait to disclose, the harder they find it, which stands to reason because the child's default impression of aligned social and biological parentage would have been misconstrued. Although there are important differences between gamete donation and adoption, the overwhelming empirical conclusion from decades of family research on adoption similarly suggests that openness from the start is most beneficial for the child (Golombok 2017).

However, it is easier to make the case for the real potential harm caused by inadvertent disclosure. The risk of inadvertent disclosure was previously thought to be mostly related to the fact that parents often tell other family members about their donor conception, whilst keeping this information from their child (Jadva et al. 2009). Pennings suggests that knowing the risk of inadvertent disclosure has so far not caused parents to disclose. This is undoubtedly correct, but that is exactly our point: with the co-spread of DTC DNA testing and the ease of finding people through social media, this is already changing.

As a result of the growth of the consumer DNA databases, unknown parentage searches are becoming easier to resolve, as is evidenced by the stories reported on a daily basis in the 
DNA Detectives Facebook group (www.facebook.com/groups/DNADetectives) which now has over 100,000 members. In a 2017 survey of adoptees who were using DNA to find their biological parents it was reported that $66.5 \%$ of respondents had identified a match with a half second cousin or closer (Bettinger 2017). Second cousins are the "sweet spot" where identification is generally a straightforward task (Moore 2016). In a survey conducted by the Facebook group We Are Donor Conceived 55\% of respondents reported that they had identified their donor, and $72 \%$ had identified donor siblings (We Are Donor Conceived 2019).

With the growing DNA databases many people are now discovering their donor origins as a result of DNA testing. In the We Are Donor Conceived survey $37 \%$ of respondents had discovered they were donor conceived after taking a commercial DNA test (We Are Donor Conceived 2019). As a result of all the unexpected DNA discoveries, two of the main consumer genetics companies now offer special training to their customer service representatives so that they can deal with these emotional situations (Brown 2018). A number of informal support groups have sprung up on Facebook to help people come to terms with their unexpected results (Zhang 2018). Private Facebook groups have also been set up for the offspring of individual donors with the largest such group consisting of 189 offspring from a single donor (Zhang 2019).

Pennings discusses anonymity from the point of view of the donors and the recipient parents, but fails to consider the rights of the donor-conceived individuals who were not a party to the contract of anonymity. The harms experienced by individuals who were denied access to their genetic origins, and hence half of their ancestry and medical history, also need to be taken into account. It is now widely recognised that the rights of the child trump the rights of the adult (Hallich 2017) and that individuals have a natural right to not to be deceived as well as a prima facie right to know their genetic heritage (Ravitsky 2017). The possibility of discovering an unexpected biological heritage is a consequence of not having been given accurate information about their biological parentage, in other words having been deceived about a central feature of their identity.

We agree that searches for donor parents, donor siblings and donor offspring are likely to disrupt lives, and there is a great need to conduct searches sensitively and with respect for the other parties affected. But Pennings states that these types of searches "violate the rights of recipients and donors". We do not agree. Care must be taken to respect the feelings of the individuals who were conceived as a result of donor conception, many of whom have been offended by the suggestion that their use of ancestry databases shows a "lack of gratitude" to the donors (Lewis 2019). It will always be a difficult balancing act. The right to knowledge does not equate to the right to contact and the right to a relationship (Lacopo 2019). The etiquette for these difficult scenarios is still evolving, but we believe that any arrangement should safeguard the rights of donor-conceived individuals and that their rights to know key information about their biological origin outweigh any parental rights to privacy.

\section{Authors}

Debbie Kennett (1), Dan Reisel (2), Joyce Harper (2)

Joyce.harper@ucl.ac.uk

1. Department of Genetics, Evolution and Environment, University College London Darwin Building, Gower Street, London WC1E 6BT, UK. 
2. Institute for Women's Health, University College London, London WC1E 6BT, UK.

\section{Conflict of interest}

None.

\section{References}

23andMe. 2019. "23andMe: About Us.” 23andMe Media Center. 2019. https://mediacenter.23andme.com/company/about-us/.

Ancestry Corporate. 2019. "Ancestry ${ }^{\circledR}$ Surpasses 15 Million Members in Its DNA Network, Powering Unparalleled Connections and Insights (Press Release)." May 21, 2019. https://www.ancestry.com/corporate/newsroom/press-releases/ancestry\%C2\%AEsurpasses-15-million-members-its-dna-network-powering-unparalleled.

Bettinger, Blaine T. 2017. "Adoptee Testing: A Study." The Genetic Genealogist (blog). January 8, 2017. http://thegeneticgenealogist.com/2017/01/08/adoptee-testing-astudy/.

Brown, Kristen V. 2018. "Surprise DNA Results Are Turning Customer-Service Reps into Therapists," December 19, 2018. https://www.bloomberg.com/news/features/201812-19/surprise-dna-results-are-turning-customer-service-reps-into-therapists.

Golombok, Susan. 2017. "Disclosure and Donor-Conceived Children." Human Reproduction 32 (7): 1532-36. https://doi.org/10.1093/humrep/dex 104.

Hallich, Oliver. 2017. "Sperm Donation and the Right to Privacy." The New Bioethics: A Multidisciplinary Journal of Biotechnology and the Body 23 (2): 107-20. https://doi.org/10.1080/20502877.2017.1355083.

Harper, Joyce C., Debbie Kennett, and Dan Reisel. 2016. "The End of Donor Anonymity: How Genetic Testing Is Likely to Drive Anonymous Gamete Donation out of Business." Human Reproduction 31 (6): 1135-40. https://doi.org/10.1093/humrep/dew065.

Ilioi, Elena, Lucy Blake, Vasanti Jadva, Gabriela Roman, and Susan Golombok. 2017. "The Role of Age of Disclosure of Biological Origins in the Psychological Wellbeing of Adolescents Conceived by Reproductive Donation: A Longitudinal Study from Age 1 to Age 14." Journal of Child Psychology and Psychiatry, and Allied Disciplines 58 (3): 315-24. https://doi.org/10.1111/jcpp.12667.

Jadva, Vasanti, Tabitha Freeman, Wendy Kramer, and Susan Golombok. 2009. "The Experiences of Adolescents and Adults Conceived by Sperm Donation: Comparisons by Age of Disclosure and Family Type." Human Reproduction 24 (8): 1909-19. https://doi.org/10.1093/humrep/dep110.

Khan, Razib, and David Mittelman. 2018. "Consumer Genomics Will Change Your Life, Whether You Get Tested or Not." Genome Biology 19 (1): 120. https://doi.org/10.1186/s13059-018-1506-1.

Lacopo, Michael D. 2019. "Uncovering Family Secrets: The Human Side of DNA Testing." In Advanced Genetic Genealogy: Techniques and Case Studies, edited by Debbie Parker Wayne, 325-37. Cushing, Texas: Wayne Research.

Lewis, Ricki. 2019. “"The Broken Promise of Anonymity'? Bioethicist's Call to Guard Identity of Sperm and Egg Donors Is Misguided." Genetic Literacy Project, April 30, 2019. https://geneticliteracyproject.org/2019/04/30/the-broken-promise-ofanonymity-bioethicists-call-to-guard-identity-of-sperm-and-egg-donors-ismisguided/. 
Moore, CeCe. 2016. "The History of Genetic Genealogy and Unknown Parentage Searches: An Insider's View." Journal of Genetic Genealogy 8 (1): 35-37. http://jogg.info/pages/vol8/editorial/moore/moore-history.html.

MyHeritage. 2018. "MyHeritage Becomes Presenting Partner of Eurovision 2019." September 26, 2018. https://eurovision.tv/story/myheritage-presenting-partnereurovision-song-contest-2019.

Pennings, Guido. 2019. "Genetic Databases and the Future of Donor Anonymity." Human Reproduction 34 (5): 786-790. https://doi.org/10.1093/humrep/dez029.

Ravitsky, Vardit. 2017. "The Right to Know One's Genetic Origins and Cross-Border Medically Assisted Reproduction." Israel Journal of Health Policy Research 6: 3 .. https://doi.org/10.1186/s13584-016-0125-0.

Readings, Jennifer, Lucy Blake, Polly Casey, Vasanti Jadva, and Susan Golombok. 2011. "Secrecy, Disclosure and Everything in-between: Decisions of Parents of Children Conceived by Donor Insemination, Egg Donation and Surrogacy." Reproductive Biomedicine Online 22 (5): 485-95. https://doi.org/10.1016/j.rbmo.2011.01.014.

Regalado, Antonio. 2019. "More than 26 Million People Have Taken an At-Home Ancestry Test.” MIT Technology Review. February 11, 2019. https://www.technologyreview.com/s/612880/more-than-26-million-people-havetaken-an-at-home-ancestry-test/.

We Are Donor Conceived. 2019. "We Are Donor Conceived 2019 Survey Results." We Are Donor Conceived. May 1, 2019. https:/www.wearedonorconceived.com/guides/weare-donor-conceived-2019-survey-results/.

Zhang, Sarah. 2018. "When a DNA Test Shatters Your Identity." The Atlantic, July 17, 2018. https://www.theatlantic.com/science/archive/2018/07/dna-test-misattributedpaternity/562928/. .2019. "The Trouble With Fathering 114 Kids.” The Atlantic. May 13, 2019. https://www.theatlantic.com/science/archive/2019/05/bachelorette-contestant-114kids-sperm-donor/589258/. 